\title{
Twelve cases of $\mathrm{Ki}-1$ positive anaplastic large cell lymphoma of skin
}

\author{
S S Banerjee, J Heald, $M$ Harris
}

\begin{abstract}
In seven of 12 cases of Ber-H2 (Ki-1) positive anaplastic large cell nonHodgkin's lymphoma (Ki-1 ALCL) disease remained localised to skin, and in five there was extracutaneous spread. Four patients had histological evidence of pre-existing or coexisting mycosis fungoides, and three patients had a long standing history of eczema or ichthyosis. In two cases the presence of a $T$ phenotype was shown in frozen sections, and in a further six cases a $T$ phenotype was firmly established in paraffin wax sections. Four patients died less than one year after presentation (two with disseminated lymphoma; two from other causes); one died at five years with widespread lymphoma and the remaining seven cases were alive one to $14 \frac{1}{2}$ years after presentation. Three of the four patients with associated mycosis fungoides had prolonged survival, contrary to the findings of previous reports which suggest secondary Ki-1 ALCL behaves aggressively.
\end{abstract}

The recognition of these tumours is important because of their relatively good prognosis. The diagnosis can be readily substantiated immunohistochemically, using a simple panel of antibodies.

The $\mathrm{Ki}-1$ antigen was originally described in Hodgkin and Reed-Sternberg cells and in a small population of cells in normal lymph nodes. ${ }^{12}$ It has subsequently been shown in activated $T$ and $B$ cells and in an uncommon form of non-Hodgkin's lymphoma described as " $\mathrm{Ki}-1$ positive anaplastic large cell lymphoma (Ki-1 ALCL)," which has been of T, $B$, or null cell type. ${ }^{3-10}$ These lymphomas have mostly been based in nodes but some have originated elsewhere. ${ }^{37-18}$ Studies of these lymphomas have recently been facilitated by the introduction of the antibody Ber- $\mathrm{H} 2$ (CD 30), which shows the presence of $\mathrm{Ki}-1$ antigen in paraffin wax sections. ${ }^{19} 20$

Despite a growing number of published findings on $\mathrm{Ki}-1$ ALCL it is still often misdiagnosed, and in this paper we present 12 cases which emphasise that this tumour frequently presents in the skin; the differential diagnosis, immunophenotypic features, and the relation to lymphomatoid papulo$\operatorname{sis}^{21-23}$ and regressing atypical histiocytosis $(\mathrm{RAH})^{24-26}$ are discussed. Long term follow up was available on most of the cases and indicates that a high proportion of cutaneous Ki-1 ALCL pursue a non-aggressive course.

\section{Methods}

Excised skin tumours were received from all cases. In cases $1,2,3,4,6,9$, and 10 more than one skin biopsy was performed. Lymph nodes were received from cases 4 through to 8. Case 4 also developed a small intestinal tumour which was resected. In all cases formalin fixed specimens were processed conventionally into paraffin wax and $5 \mu \mathrm{m}$ sections were stained with haematoxylin and eosin, Giemsa, methyl green pyronin and reticulin stains. Immunohistochemical studies were done on paraffin wax sections using the avidin-biotin-peroxidase technique. The antibodies used are listed in table 1 . The tests were done with appropriate positive and negative controls.

Fresh tissue was available from the lymph nodes in cases 4 and 7 and this was subjected to frozen section immunoperoxidase studies for detailed phenotyping. The following antibodies were used: Anti IgD, IgM, anti- $\kappa$ and $\lambda$ light chains, $T$-lineage markers CD2, $\mathrm{CD} 3, \mathrm{CD} 5, \mathrm{CD} 4$ ( $\mathrm{T}$ helper/inducer cells), CD8 ( $T$ cytotoxic/suppressor cells) and B-lineage markers CD19, CD20, and CD22. The CD20 was supplied by Becton-Dickinson, CD 3 by Unipath, and the rest were obtained from Dakopatts.

\section{CLINICAL FINDINGS}

The clinical findings are summarised in table 2 . Eleven of the 12 patients were men with an age range from 27 to 73 years. They presented with plaque-like, nodular, or ulcerated skin lesions. Case 5 presented with an inflamed chest wall nodule initially thought to be an abscess; this was not biopsied but was clinically identical with the lymphomatous deposit confirmed by biopsy which subsequently developed in his axillary skin. Similarly, case 10 presented with a red and tender swelling of the scrotum which was clinically diagnosed as an inflammatory lesion. In most cases lesions had been present for several months and a tendency for earlier lesions to regress spontaneously was noted by two patients (cases 1 and 3 ).

A history of pre-existing or coexisting skin disease was obtained in seven cases. Two patients (cases 1 and 6 ) had had eczematous dermatitis since childhood and a skin biopsy specimen taken from case 6 showed features of chronic dermatitis. Case 7 had a dry ichthyotic skin. Four patients (cases 2, 3, 4, and 10) 
Table 1 Antibodies used for paraffin wax section immunohistochemistry

\begin{tabular}{|c|c|c|}
\hline Antibody (CD Number) & Major specificity & Source \\
\hline 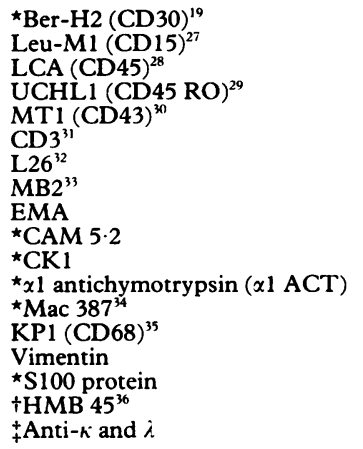 & $\begin{array}{l}\text { Reed-Sternberg cells, activated T and B cells } \\
\text { Reed-Sternberg cells, granulocytes } \\
\text { Leucocytes } \\
\text { T cells, myeloid cells } \\
\text { T cells, myeloid cells, macrophages, B cell subset } \\
\text { T cells } \\
\text { B cells } \\
\text { B cells, T cell subset } \\
\text { Epithelial cells, plasma cells, etc. } \\
\text { Cytokeratin (8, 18, and 19) } \\
\text { Cytokeratin ( } 6 \text { and } 18) \\
\text { Macrophages, granulocytes, and a variety of other cells } \\
\text { Macrophages, myeloid cells } \\
\text { Macrophages, myeloid cells } \\
\text { Mesenchymal cells, some epithelial cells, lymphoid cells, etc } \\
\text { Langerhans' cells, Schwann cells, melanocytes, etc } \\
\text { Activated and malignant melanocytes } \\
\text { B cells }\end{array}$ & $\begin{array}{l}\text { Dakopatts } \\
\text { Becton Dickinson } \\
\text { Dakopatts } \\
\text { Dakopatts } \\
\text { Clonab } \\
\text { Dakopatts } \\
\text { Dakopatts } \\
\text { Clonab } \\
\text { Dakopatts } \\
\text { Becton Dickinson } \\
\text { Dakopatts } \\
\text { Dakopatts } \\
\text { Dakopatts } \\
\text { Dakopatts } \\
\text { Dakopatts } \\
\text { Dakopatts } \\
\text { Enzobiochem } \\
\text { Dakopatts }\end{array}$ \\
\hline
\end{tabular}

* Sections were treated with trypsin.

tDone only on cases 3 and 6 where a suggestion of melanoma was initialy made.

†Done in case 6 which showed only MB2 positivity.

x1 ACT, EMA, and S100 protein were polyclonal and the rest were monoclonal antibodies.

Table 2 Clinical findings

\begin{tabular}{|c|c|c|c|c|c|c|c|c|c|c|c|}
\hline $\begin{array}{l}\text { Case } \\
\text { No }\end{array}$ & $\begin{array}{l}\text { Age } \\
\operatorname{sex}\end{array}$ & Presentation & $\begin{array}{l}\text { Pre- or co- } \\
\text { existing skin } \\
\text { disease }\end{array}$ & $\begin{array}{l}\text { Initial } \\
\text { pathological } \\
\text { diagnosis }\end{array}$ & Treatment & Course & $\begin{array}{l}\text { Current } \\
\text { state }\end{array}$ & $\begin{array}{l}\text { Survival } \\
\text { (months) }\end{array}$ & $\begin{array}{l}\text { Extra- } \\
\text { cutaneous } \\
\text { disease at } \\
\text { referral }\end{array}$ & $\begin{array}{l}\text { Bone } \\
\text { marrow } \\
\text { disease }\end{array}$ & $\begin{array}{l}\text { Consti- } \\
\text { tutional } \\
\text { symptoms }\end{array}$ \\
\hline 1 & $36 \mathrm{M}$ & $\begin{array}{l}\text { Multiple skin } \\
\text { nodules on trunk } \\
\text { and limbs }\end{array}$ & $\begin{array}{l}\text { Longstanding } \\
\text { eczema }\end{array}$ & $\begin{array}{l}\text { Undifferentiated } \\
\text { tumour }\end{array}$ & $\begin{array}{l}\text { Radiotherapy } \\
\text { and } \\
\text { chemotherapy }\end{array}$ & $\begin{array}{l}\text { Skin } \\
\text { recurrences } \\
\times 4\end{array}$ & Alive & 60 & None & None & None \\
\hline 2 & $50 \mathrm{M}$ & $\begin{array}{l}\text { Multiple skin } \\
\text { nodules on left } \\
\text { leg }\end{array}$ & $\begin{array}{l}\text { Mycosis } \\
\text { fungoides }\end{array}$ & $\begin{array}{l}\text { ?Hodgkin's } \\
\text { disease ?reactive } \\
\text { process }\end{array}$ & Radiotherapy & $\begin{array}{l}\text { Skin } \\
\text { recurrences } \\
\times 3\end{array}$ & Alive & 87 & None & None & None \\
\hline 3 & $65 M$ & $\begin{array}{l}\text { Single ulcerated } \\
\text { lesion on right } \\
\text { leg }\end{array}$ & $\begin{array}{l}\text { Mycosis } \\
\text { fungoides }\end{array}$ & $\begin{array}{l}\text { Malignant } \\
\text { melanoma }\end{array}$ & $\begin{array}{l}\text { Surgical } \\
\text { excision and } \\
\text { radiotherapy }\end{array}$ & $\begin{array}{l}\text { Skin } \\
\text { recurrence } \\
\text { after } 12 \text { years }\end{array}$ & Alive & 174 & None & N/D & None \\
\hline 4 & $70 \mathrm{~F}$ & $\begin{array}{l}\text { Recurrent scalp } \\
\text { nodules }\end{array}$ & $\begin{array}{l}\text { Mycosis } \\
\text { fungoides }\end{array}$ & $\begin{array}{l}\text { Anaplastic } \\
\text { malignant } \\
\text { tumour }\end{array}$ & Radiotherapy & $\begin{array}{l}\text { Skin, nodal, } \\
\text { and small } \\
\text { intestinal } \\
\text { recurrences }\end{array}$ & Dead $\dagger$ & 60 & None & $\mathbf{N} / \mathbf{D}$ & None \\
\hline 5 & $27 \mathrm{M}$ & $\begin{array}{l}\text { Abscess-like } \\
\text { lesion of chest- } \\
\text { wall; axillary } \\
\text { lymph nodes }\end{array}$ & None & $\begin{array}{l}\text { Anaplastic (Ki-1 } \\
\text { positive) non- } \\
\text { Hodgkin's } \\
\text { lymphoma } \\
\text { (lymph node } \\
\text { biopsy) }\end{array}$ & Chemotherapy & $\begin{array}{l}\text { Rapid } \\
\text { recurrence of } \\
\text { cellulitis-like } \\
\text { skin lesion }\end{array}$ & Dead $\dagger$ & 7 & $\begin{array}{l}\text { Lymph } \\
\text { node; } \\
\text { ?lung }\end{array}$ & None & $\begin{array}{l}\text { Weight } \\
\text { loss }\end{array}$ \\
\hline 6 & $31 \mathrm{M}$ & $\begin{array}{l}\text { Nodules on } \\
\text { temple and chin; } \\
\text { neck nodes }\end{array}$ & $\begin{array}{l}\text { Long standing } \\
\text { eczema }\end{array}$ & $\begin{array}{l}\text { ?Large cell } \\
\text { lymphoma } \\
\text { (?histiocytic) } \\
\text { ?malignant } \\
\text { melanoma }\end{array}$ & $\begin{array}{l}\text { Radiotherapy } \\
\text { and } \\
\text { chemotherapy }\end{array}$ & $\begin{array}{l}\text { Nodal and } \\
\text { hepatic } \\
\text { recurrence } \\
\text { (ultra-sound } \\
\text { and } \\
\text { computed } \\
\text { tomographic } \\
\text { scan) }\end{array}$ & Dead $\dagger$ & 9 & $\begin{array}{l}\text { Lymph } \\
\text { node; } \\
\text { ?liver }\end{array}$ & None & None \\
\hline 7 & $69 \mathrm{M}$ & $\begin{array}{l}\text { Single skin } \\
\text { nodule on arm; } \\
\text { axillary lymph } \\
\text { node }\end{array}$ & $\begin{array}{l}\text { Dry, ichthyotic } \\
\text { skin }\end{array}$ & $\begin{array}{l}\text { Undifferentiated } \\
\text { tumour }\end{array}$ & Chemotherapy & $\begin{array}{l}\text { No } \\
\text { recurrences, } \\
\text { terminal } \\
\text { fungal } \\
\text { infection }\end{array}$ & Dead & 2 & $\begin{array}{l}\text { Lymph } \\
\text { node }\end{array}$ & None & None \\
\hline 8 & $33 \mathrm{M}$ & $\begin{array}{l}\text { Single skin } \\
\text { nodule on back; } \\
\text { axillary lymph } \\
\text { nodes }\end{array}$ & None & $\begin{array}{l}\text { ?Hodgkin's } \\
\text { disease }\end{array}$ & Radiotherapy & $\begin{array}{l}\text { No } \\
\text { recurrences }\end{array}$ & Alive & 66 & $\begin{array}{l}\text { Lymph } \\
\text { node }\end{array}$ & None & None \\
\hline 9 & $48 M$ & $\begin{array}{l}\text { Multiple skin } \\
\text { nodules on lip, } \\
\text { nose, right arm } \\
\text { and right leg }\end{array}$ & None & $\begin{array}{l}\text { ?Malignant } \\
\text { histiocytosis } \\
\text { ?T cell } \\
\text { lymphoma }\end{array}$ & $\begin{array}{l}\text { Surgical } \\
\text { excision and } \\
\text { chemotherapy }\end{array}$ & $\begin{array}{l}\text { Skin } \\
\text { recurrence-- } \\
\text { nose and left } \\
\text { arm after } 9 \\
\text { years }\end{array}$ & Alive & 110 & None & None & None \\
\hline 10 & $73 \mathrm{M}$ & $\begin{array}{l}\text { Hard and tender } \\
\text { swelling of left } \\
\text { scrotum with } \\
\text { focal gangrenous } \\
\text { change }\end{array}$ & $\begin{array}{l}\text { Mycosis } \\
\text { fungoides }\end{array}$ & $\begin{array}{l}\text { Pleomorphic } \\
\text { malignant fibrous } \\
\text { histiocytoma }\end{array}$ & $\begin{array}{l}\text { Surgery and } \\
\text { radiotherapy }\end{array}$ & $\begin{array}{l}\text { No } \\
\text { recurrence }\end{array}$ & Dead & 6 & None & N/D & None \\
\hline 11 & $62 \mathrm{M}$ & $\begin{array}{l}\text { Thickening and } \\
\text { induration of } \\
\text { skin right elbow }\end{array}$ & None & $\begin{array}{l}\text { Non-Hodgkin's } \\
\text { lymphoma }\end{array}$ & Radiotherapy & $\begin{array}{l}\text { No } \\
\text { recurrence }\end{array}$ & Alive & 16 & None & N/D & None \\
\hline 12 & $36 \mathrm{M}$ & $\begin{array}{l}\text { Plaque-like skin } \\
\text { lesion right neck }\end{array}$ & None & $\begin{array}{l}\text { Inflammatory } \\
\text { lesion }\end{array}$ & $\begin{array}{l}\text { Surgical } \\
\text { excision }\end{array}$ & $\begin{array}{l}\text { Skin } \\
\text { recurrence } \\
1.5 \mathrm{~cm} \text { above } \\
\text { the previous } \\
\text { lesion after } \\
10 \text { months }\end{array}$ & Alive & 12 & None & None & None \\
\hline
\end{tabular}

$\mathrm{N} / \mathrm{D}=$ Not done.

*After development of $\mathrm{Ki}-1$ ALCL.

iDeath directly attributable to lymphoma. 
Figure 1 Case 3: mycosis fungoides showing intermediate sized lymphocytes containing convoluted nuclei which invade the dermis and acanthotic epidermis. numerous small and

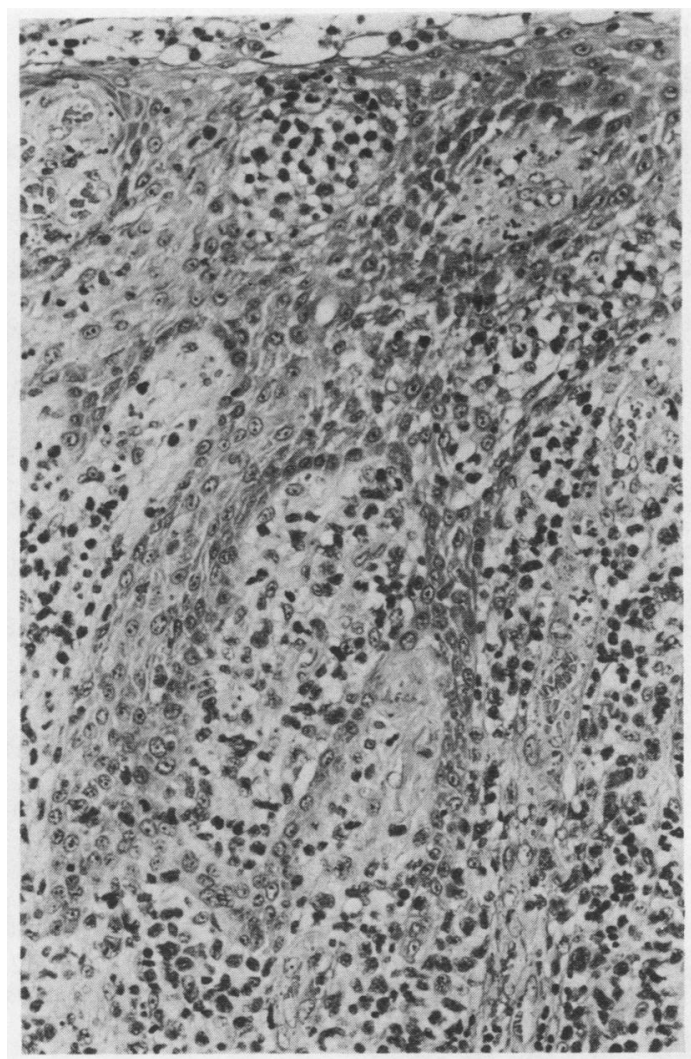

had mycosis fungoides confirmed at biopsy (fig 1). In cases 3 and 4 the mycotic skin lesions had been present for about 12 years, while in case 10 a generalised psoriasiform skin rash had been present for several years; a biopsy specimen taken three months before the development of the scrotal lesion showed features consistent with mycosis fungoides. In case 2 histological features of mycosis fung-

Figure 2 Case 3: low power view of the cutaneous infiltrate of $\mathrm{Ki}-1 \mathrm{ALCL}$. The epidermis (*) is spared and the deeper dermis is occupied by a polymorphic infiltrate.

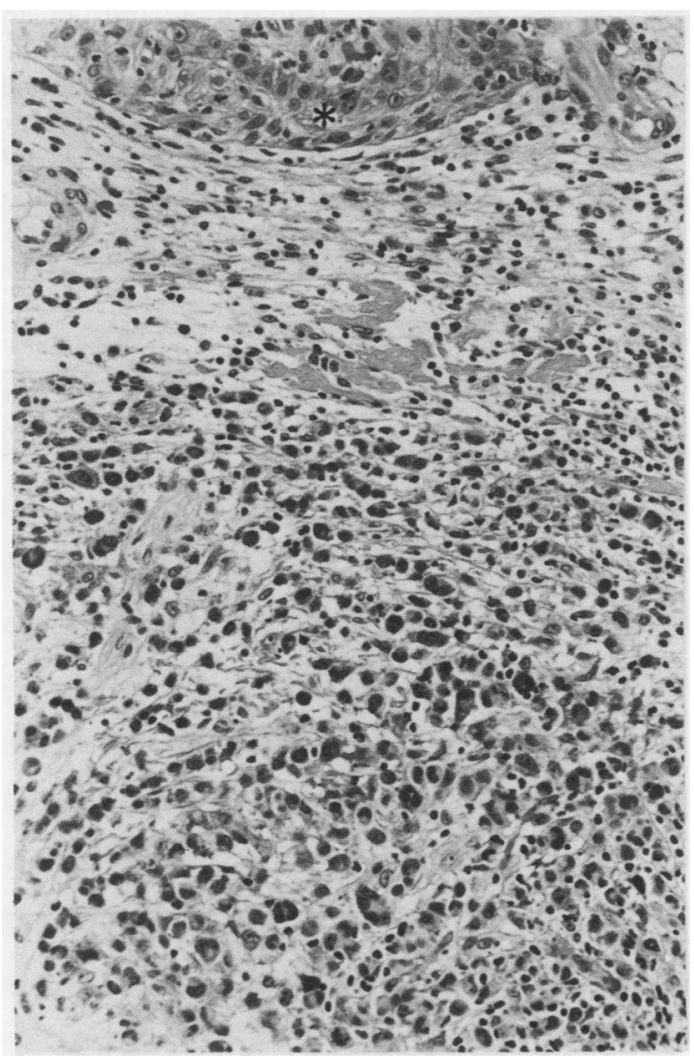

oides were found in a long standing rash biopsied concurrently with the recently developed nodules of $\mathrm{Ki}-1$ ALCL. In case 8 , the skin lesion developed at the site of a jelly fish sting and was present for four years, enlarging slowly, before biopsy.

Treatment varied depending on the initial clinicopathological diagnosis and extent of disease, but in seven patients the disease remained localised to the skin. Seven patients are still alive between 12 and 174 months after the development of $\mathrm{Ki}-1$ ALCL. Five patients (cases 1, 2, 3, 8, and 9) were followed up for more than five years, two of whom had mycosis fungoides. One patient (case 4) died five years after her mycosis fungoides transformed into $\mathrm{Ki}-1 \mathrm{ALCL}$ and during this period she had nodal and small intestinal disease. The shortest survival times of seven, nine, two, and six months occurred in cases 5 , 6,7 , and 10, respectively. Case 10 had severe chronic obstructive airways disease and died of respiratory failure. In case 7 necropsy showed death to have been due to fungal infection of the gastrointestinal tract, with no viable tumour present. Only in cases 4,5 , and 6 , therefore, was death directly attributable to the dissemination of lymphoma.

\section{Results}

\section{HISTOLOGICAL FINDINGS}

The neoplastic component of the cutaneous infiltrate was morphologically similar in all cases, being composed of large cells with abundant eosinophilic, basophilic, or clear cytoplasm and central or eccentric, indented, convoluted or multilobulated nuclei with one or more prominent nucleoli (figs 2 and 3). Multinucleated cells were also present, and nuclei in some of these cells were arranged in a wreathlike fashion. Mitotic figures were conspicuous. There was a variable accompanying infiltrate of lymphocytes, eosinophils, plasma cells and histiocytes. Occasional Hodgkin and ReedSternberg-like cells were seen in a few cases.

The infiltrate tended to be cohesive, dense, and diffuse, being centred on the dermis and showing variable extension into the subcutaneous fat. Extension up to the dermoepidermal junction was present in two cases but there was no epidermotropism. Epidermal ulceration was present in biopsy specimens from three cases. In case 10 there was a vigorous fibroblastic proliferation within the lesion which produced a sarcomatoid appearance in places. Focal myxoid change was noted in two cases.

The small intestinal deposit in case 4 (fig 4) and the nodal deposits in cases 4-8 were morphologically similar to the skin infiltrate. There was paracortical or diffuse disease in the lymph nodes and full thickness infiltration of the small bowel wall in case 4 . The intestinal mucosa overlying the tumour was ulcerated but the rest of the mucosa was normal and showed no evidence of villous atrophy.

We attempted to subclassify the cases into types I and II as proposed by Chan et al $^{8}$; using their criteria, we found a clear distinction difficult to achieve but felt that all cases probably fell into the type II category. 


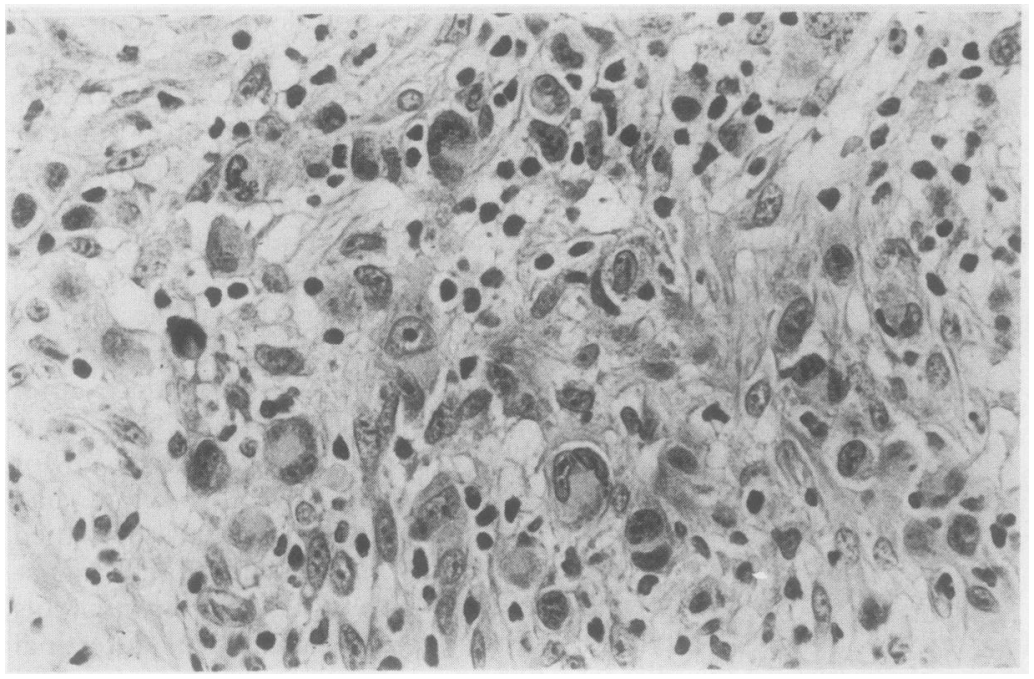

Figure 3 Case 3: high power view of the neoplastic cells. Mononuclear, binucleate, and multinucleate cells with abundant cytoplasm are seen. Many cells have eccentrically placed nuclei.

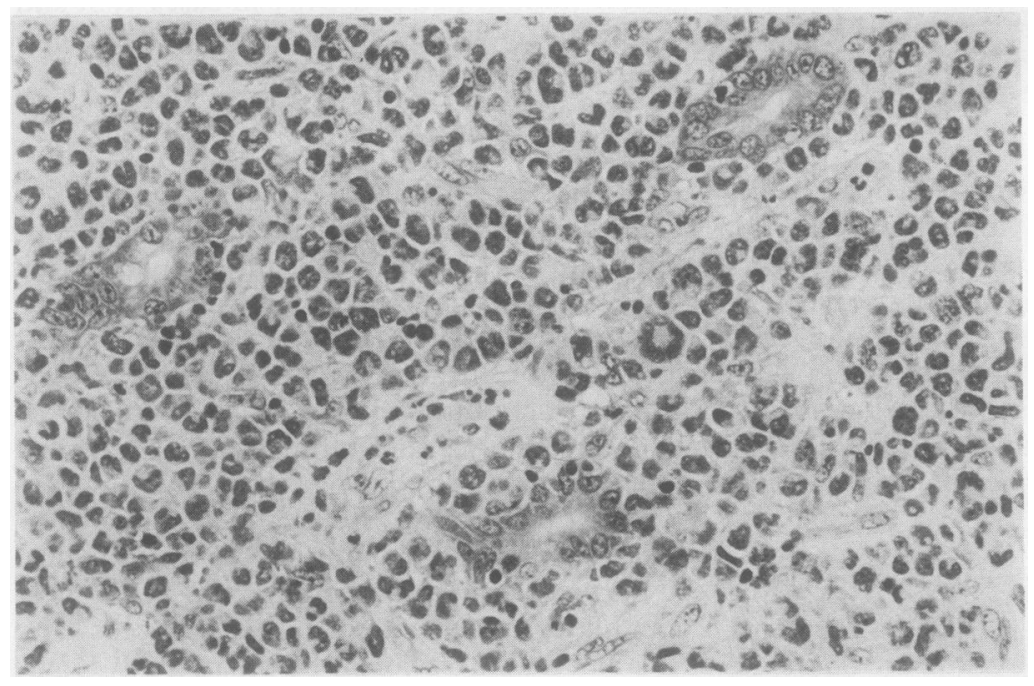

Figure 4 Case 4: small intestinal disease as a result of $K i-1 A L C L$.

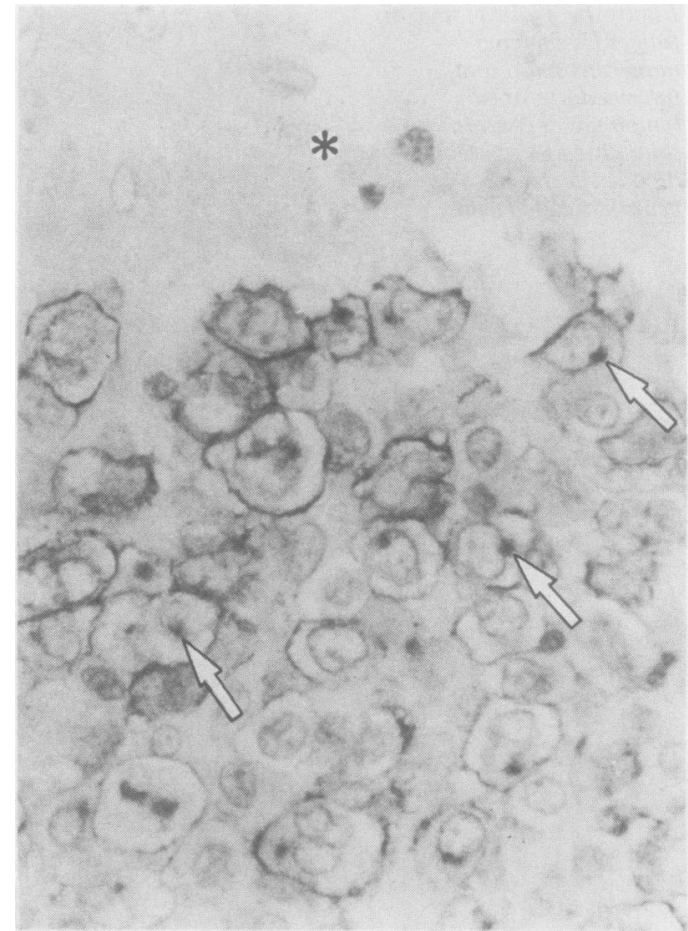

Figure 5 Case 1: Ber-H2 positive neoplastic cells. Note the strong membrane and paranuclear positivity (arrow); * $=$ epidermis.

\section{IMMUNOHISTOCHEMICAL FINDINGS}

The immunohistochemical findings are summarised in table 3; the results for recurrent skin lesions and for nodal and small intestinal deposits are combined unless otherwise indicated. In all cases most or all of the neoplastic cells were strongly positive with Ber-H2 (CD30), which shows the presence of the $\mathrm{Ki}-1$ antigen. Staining was present both on the cell membrane and within the cytoplasm, and in some cases was particularly concentrated in a paranuclear location (fig 5).

Leucocyte common antigen (LCA) was present in skin lesions from nine of the 12 cases but was absent from nodal and small intestinal recurrences in cases 4,6 , and 7 and could not be shown in the initial or recurrent cutaneous lesions in cases 3,8 , and 10 .

Table 3 Immunohistochemical results

\begin{tabular}{|c|c|c|c|c|c|c|c|c|c|c|c|c|c|c|c|c|c|}
\hline $\begin{array}{l}\text { Case } \\
\text { No }\end{array}$ & $\begin{array}{l}\text { Ber-H2 } \\
(C D 30)\end{array}$ & $\begin{array}{l}\text { Leu-M1 } 1^{a} \\
(C D 15)^{2}\end{array}$ & $\begin{array}{l}L C A^{b} \\
\text { (CD45) }\end{array}$ & $\begin{array}{l}\text { UCHL1 } \\
\text { (CD45RO) }\end{array}$ & $\begin{array}{l}M T 1 \\
C C D 43\end{array}$ & $C D 3$ & $L 26$ & $M B 2^{x}$ & $E M A$ & $\begin{array}{l}C A M \\
5 \cdot 2\end{array}$ & $C K 1$ & $\alpha 1 A C T^{d}$ & Mac 387 & $\begin{array}{l}K P 1 \\
(C D 68)\end{array}$ & Vimentin & $\begin{array}{l}\text { S100 } \\
\text { protein }\end{array}$ & $\begin{array}{l}H M B \\
45\end{array}$ \\
\hline 1 & + & - & + & + & + & - & - & - & - & - & - & - & - & - & + & - & ND \\
\hline $\begin{array}{l}2 \\
3\end{array}$ & + & - & \pm & $\bar{I}$ & + & $\overline{+}$ & - & - & + & - & - & - & - & - & + & - & ND \\
\hline & & & - & + & + & $\stackrel{+}{\text { Weak }}$ & & & & - & & - & & & + & & \\
\hline $4^{\star}$ & + & - & + & - & - & + & - & - & - & - & - & - & - & - & + & - & ND \\
\hline 5 & + & - & + & + & + & - & - & - & + & - & - & - & - & - & - & - & ND \\
\hline $7_{7^{\star}}^{6}$ & $\begin{array}{l}+ \\
+\end{array}$ & $\overline{-}$ & $\stackrel{+}{+}$ & $\overline{-}$ & $\bar{t}$ & $\overline{-}$ & $\overline{-}$ & $\stackrel{+}{+}$ & $=$ & $\overline{-}$ & $\overline{-}$ & \pm & $\bar{z}$ & $\overline{-}$ & + & $\overline{-}$ & $\overline{\mathrm{ND}}$ \\
\hline & & & Focal & & - & & & & & & & & & & & & \\
\hline $\begin{array}{l}8 \\
9\end{array}$ & $\begin{array}{l}+ \\
+\end{array}$ & - & $\bar{t}$ & $\bar{t}$ & $\overline{-}$ & $\begin{array}{l}\text { ND } \\
+\end{array}$ & $=$ & - & $\bar{z}$ & $\bar{z}$ & $=$ & 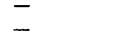 & $=$ & $=$ & $\begin{array}{l}+ \\
+\end{array}$ & $\overline{-}$ & $\begin{array}{l}\text { ND } \\
\text { ND }\end{array}$ \\
\hline 10 & + & & & & Focal & Weak & k & & & & & 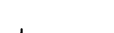 & & & & & ND \\
\hline 10 & + & - & - & - & $\stackrel{+}{\text { Focal }}$ & & - & - & - & - & - & + & - & - & - & - & ND \\
\hline 11 & + & - & + & + & + & $\stackrel{+}{+}$ & - & - & - & - & - & - & - & - & + & - & ND \\
\hline 12 & + & - & + & + & + & ND & - & - & - & - & - & - & - & - & + & - & ND \\
\hline
\end{tabular}

"Positive in recurrent skin lesions in case 3 and small intestinal disease in case 4.

'Negative in nodal and intestinal disease in case 4, nodal recurrence in case 6 and node in case 7.

Positive in nodal and intestinal disease in case 4 ; node negative in case 7.

${ }^{\mathrm{N}}$ Negative in nodal recurrence in case 6.

*In cases 4 and $7 \mathrm{~T}$ cell markers were shown in frozen sections.

+ Positive; - negative; ND-not done. 
Figure 6 Case 4: strong paranuclear Leu-M1 positivity in the intestinal recurrence.

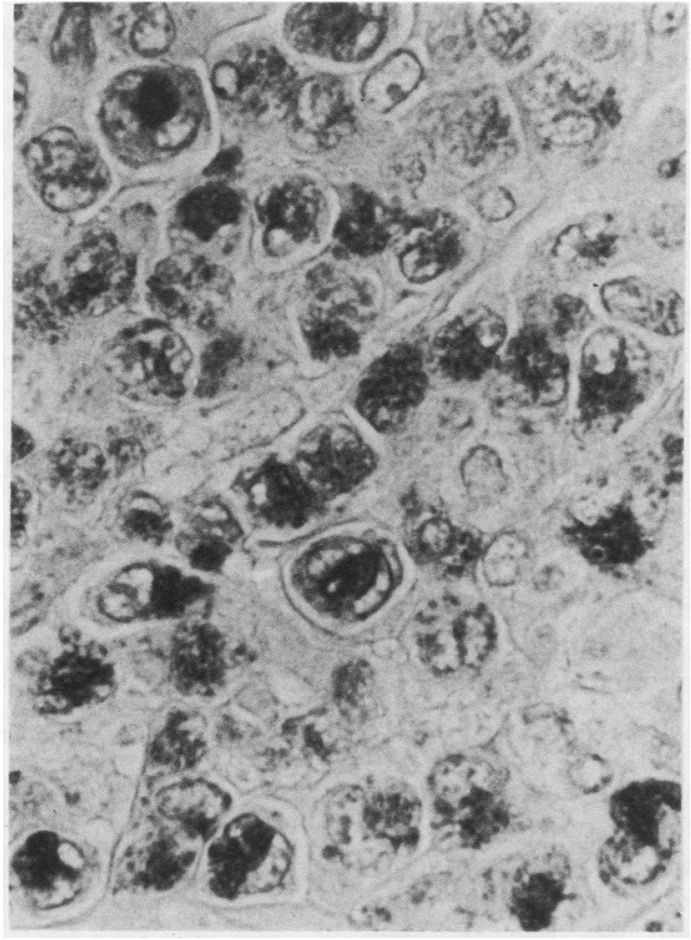

Leu-M1 staining was absent from the initial skin lesions in all cases. In case 3 focal cytoplasmic positivity was noted in a recurrent skin deposit, but not in the initial biopsy specimen. Strong staining of the paranuclear cytoplasm was present in most of the neoplastic cells in the small intestinal recurrence of case 4 (fig 6).

Staining for $\mathrm{T}$ cell markers on paraffin wax sections showed both UCHL1 and MT1 positivity in six cases, three of which were also weakly positive for CD3. Case 4 was also CD3 positive. Three cases showed only MT1 positivity. Staining was absent in paraffin waxembedded tissue from cases 6 and 8. Immunostains done on fresh frozen material from case 4 were consistent with $\mathrm{T}$ cell lymphoma of helper subtype (CD2, CD3, and CD4 positive). In case 7 frozen sections were CD3 negative, but positive for $\mathrm{CD} 2$ and $\mathrm{CD} 4$.

The pan-B marker L26 could not be detected in any biopsy specimen. MB2, a pan-B marker, which may stain a proportion of $\mathrm{T}$ cell lymphomas, was present in cases 6 and 7 and in nodal and gut recurrences in case 4. As indicated above in cases 4 and 7 the frozen section immunostains established a $\mathrm{T}$ lineage. In case 6 the neoplastic cells were negative for $\mathrm{T}$ cell markers and also for the light chains.

A further notable feature was strong paranuclear positivity for vimentin in 10 cases. Electron microscopical examination of one of the cases confirmed the presence of abundant intermediate filaments in this location.

al ACT was shown in two cases but the histiocyte markers Mac 387 and KPI were negative in all specimens. Only two cases were positive for epithelial membrane antigen (EMA).

\section{Discussion}

Most reported $\mathrm{Ki}-1$ ALCL have been cases which presented with nodal disease, but skin disease is not uncommon and figures culled from the major published series on $\mathrm{Ki}-1 \mathrm{ALCL}$ show that associated skin disease occurs in about $15 \%$ of cases. ${ }^{3-18}$ It is this aspect which we emphasise in this report. It is not our purpose to review the subject of $\mathrm{Ki}-1 \mathrm{ALCL}$ in general as this is well covered by other publications. ${ }^{36-1013}$ It is worth noting that the wide age range of our patients (27-73 years) is similar to that reported by Kaudewitz et al, ${ }^{14}$ although others have emphasised a high incidence in children. ${ }^{71}$ As in other studies, ${ }^{781013}$ our patients are predominantly male.

The anaplastic histological appearance of these lymphomas led to a wide range of initial pathological diagnoses, including Hodgkin's disease, metastatic carcinoma, malignant melanoma, malignant fibrous histiocytoma and an "unusual reactive process." This has also been the experience of others who also include lymphomatoid papulosis, RAH, and malignant histiocytosis among the diagnoses encountered. $^{78}$

Once they become familiar, the histological appearances of $\mathrm{Ki}-1 \mathrm{ALCL}$ are rather characteristic but they require immunohistochemical confirmation. This can be achieved by using commercially available antibodies on formalin fixed, paraffin wax embedded tissue. The strong membrane and paranuclear Ber- $\mathrm{H} 2$ positivity in most of the neoplastic cells is the most important diagnostic feature. The presence of LCA positivity in most of our cases excludes the possibility of a metastatic carcinoma or malignant melanoma, although a proportion of $\mathrm{Ki}-1$ ALCL may be LCA negative. ${ }^{6891320}$ Absence of cytokeratins is further evidence against a diagnosis of metastatic carcinoma. In this context it is worth noting that embryonal carcinomas and some pancreatic carcinomas show strong Ber-H2 staining, ${ }^{47}$ but these would probably be positive for cytokeratins. Many Ki-1 ALCL express EMA which may be another source of confusion..$^{6-9} 20$ In our series only two cases exhibited EMA positivity.

S100 protein, the presence of which can usually be shown in malignant melanomas, was absent in all our cases. Cases 3 and 6, in which the possibility of melanoma was initially suggested, were stained for a melanoma specific marker HMB $45^{36}$ but both yielded negative results. The failure to show $\mathrm{S} 100$ protein also precludes a diagnosis of Langerhans' cell histiocytosis which may conceivably be confused with $\mathrm{Ki}-1 \mathrm{ALCL}$ on morphological grounds.

Reed-Sternberg and Hodgkin cells are also Ber-H2 positive but skin disease is exceedingly rare in Hodgkin's disease, particularly as a presenting clinical feature. ${ }^{22} 38$ Histological features which are useful for differentiating $\mathrm{Ki}-1$ ALCL from Hodgkin's disease are dense concentration of neoplastic cells, their cohesive nature, and sparsity of typical Hodgkin or Reed-Sternberg cells in the former condition. Moreover, Reed-Sternberg cells are rarely LCA positive. ${ }^{20} 28$

True histiocytic lymphomas, which may affect skin, can occasionally be $\mathrm{Ki}-1$ positive, 
but are also positive for histiocyte markers KP1 (CD68) and Mac 387 which are not found in $\mathrm{Ki}-1$ ALCL. ${ }^{39} 40$

Most reported cases of $\mathrm{Ki}-1 \mathrm{ALCL}$ are of T lineage $\mathrm{e}^{35-18}$; this is substantiated in the present series and provides useful additional diagnostic information. The specific $\mathrm{T}$ cell marker CD3 may be absent or only weakly expressed, however, as in this and other series, ${ }^{914}$ and should not be relied on for evidence of $T$ lineage in these tumours.

Both lymphomatoid papulosis and $\mathrm{RAH}^{21-26}$ present with cutaneous nodules which regress and recur. Although they were originally regarded as benign it is now recognised that they can progress to frank lymphoma. They show morphological similarities to $\mathrm{Ki}-1 \mathrm{ALCL}^{7814}$ and have been shown to be of $\mathrm{T}$ lineage and to be monoclonal. ${ }^{264142}$ Lymphomatoid papulosis is also $\mathrm{Ki}-1$ positive. ${ }^{4}$

Our cases $1,2,3,8,9,11$, and 12 , with their apparently benign course, might be regarded as examples of lymphomatoid papulosis or RAH, but we could find no morphological or phenotypic differences between them and the cases which spread systemically. We share the view of Chan et al ${ }^{8}$ and Kaudewitz et al ${ }^{14}$ that RAH, lymphomatoid papulosis, and cutaneous $\mathrm{Ki}-1$ ALCL are the same disease under different names.

Seven of our patients gave a history of pre- or coexisting chronic skin disease. In three this was described as eczema or ichthyosis, only one of them was biopsied and the histology was of chronic dermatitis. In the other four patients the diagnosis of mycosis fungoides was confirmed by biopsy; staining for $\mathrm{Ki}-1$ antigen with Ber-H2 was negative in all these biopsy specimens. The clinical importance of the association with eczema or ichthyosis is uncertain, but the relation of $\mathrm{Ki}-1 \mathrm{ALCL}$ with mycosis fungoides has been previously recor$\operatorname{ded}^{61443}$ and has been referred to as secondary $\mathrm{Ki}-1$ lymphoma. ${ }^{14}$ It has been suggested that such transformed cases behave aggressively with rapid systemic progression, ${ }^{14} 43$ but our experience is different; two of our four cases were alive without dissemination at 87 and 174 months, respectively, one dying at 60 months with disseminated disease and one dying of unrelated disease six months after presentation.

It is also worth noting that there is a reported association between lymphomatoid papulosis and mycosis fungoides, ${ }^{22}{ }^{23}$ lending some support to the view expressed above that lymphomatoid papulosis and $\mathrm{Ki}-1$ ALCL are the same disease.

Despite their alarming histological appearances cutaneous $\mathrm{Ki}-1$ ALCL usually have a relatively good prognosis. ${ }^{8141518}$ Of our 12 cases, seven remained localised to the skin, one showed prolonged survival despite spread to lymph nodes and intestine, and seven were alive from 12 to 174 months after diagnosis confirmed by biopsy. In only three patients was death directly attributable to the neoplastic process, and in one of these (case 5) appropriate treatment was delayed because the skin lesion was clinically misdiagnosed as inflammatory.
In the series of Chan et al all five cutaneous cases were alive at one to three years after presentation. ${ }^{8}$ These authors suggested that $\mathrm{Ki}-1 \mathrm{ALCL}$ could be divided into two histological subtypes and that type I was more aggressive than type II. We have found this subtyping difficult to achieve but tentatively regard all our cases as type II.

In conclusion, we emphasise that the accurate recognition of these tumours is important because of their relatively good prognosis and that the diagnosis can be substantiated immunohistochemically using a simple panel of antibodies reactive in formalin fixed, paraffin wax embedded tissues.

We thank Mrs L Garstang for typing the manuscript. We are grateful to Dr H Ali of Huddersfield Royal Infirmary, Dr S Banik of Blackburn Royal Infirmary, and Dr L J McWilliam of Withington Hospital, Manchester, for providing clinical information and pathological material in three of our cases.

We also thank Mr D Edmondson and $\mathrm{Mr} \mathrm{K} \mathrm{J} \mathrm{Elsam} \mathrm{for}$ technical assistance.

Schwab U, Stein H, Gerdes J, et al. Production of a monoclonal antibody specific for Hodgkin and Sternberg . lymphoid cells. Nature 1982;299:65-7.

2 Stein $\mathrm{H}$, Gerdes J, Schwab U, et al. Identification of Hodgkin and Sternberg-Reed cells as a unique cell type derived from a newly-detected small-cell population. Cancer 1982;30:445-59.

3 Stein H, Mason DY, Gerdes J, et al. The expression of the Hodgkin's disease associated antigen $\mathrm{Ki}-1$ in reactive and neoplastic lymphoid tissue: Evidence that Reed-Sternberg cells and histiocytic malignancies are derived from berg cells and histiocytic malignancies are deri

4 Pallesen G. The diagnostic significance of the CD $30(\mathrm{Ki}-1)$ antigen. Histopathology 1990;16:409-13.

5 O'Connor NTJ, Stein H, Gatter KC, et al Genotypic analysis of large cell lymphomas which express the $\mathrm{Ki}-1$ antigen. Histopathology 1987;11:733-40.

6 Suchi T, Lennert K, Tu L-Y, et al. Histopathology and immunohistochemistry of peripheral $\mathrm{T}$ cell lymphomas: a proposal for their classification. J Clin Pathol 1987; 40:995-1015.

7 Agnarsson $\mathrm{BA}$, Kadin $\mathrm{ME}$. $\mathrm{Ki}-1$ positive large cell lymphoma: A morphologic and immunologic study of 19 cases. Am J Surg Pathol 1988;12:264-74.

8 Chan JKC, Ng CS, Hui PK, et al. Anaplastic large cell Ki-1 lymphoma. Delineation of two morphological types. Histopathology 1989;15:11-34.

9 Delsol G, AlSaati T, Gatter KC, et al. Coexpression of epithelial membrane antigen (EMA), $\mathrm{Ki}-1$, and interleukin-2 receptor by anaplastic large cell lymphomas. Diagnostic value in so-called malignant histiocytosis. $\mathrm{Am}$

10 Tashiro K, Kikuchi M, Takeshita M, Yoshida T, Ohshima $\mathrm{K}$. Clinicopathological study of $\mathrm{Ki}-1$ positive lymphomas. Pathol Res Pract 1989;185:461-7.

11 Kadin ME, Sako D, Berliner N, et al. Childhood Ki-1 lymphoma presenting with skin lesions and peripheral lymphadenopathy. Blood 1986;68:1042-9.

12 Nasu K, Said J, Vonderheid E, Olerud J, Sako D, Kadin M. Immunopathology of cutaneous T-cell lymphomas. $\mathrm{Am} \mathrm{J}$ Pathol 1985;119:436-47.

13 Chott A, Kaserer K, Augustin I, et al. $\mathrm{Ki}-1$ positive large cell lymphoma. A clinicopathologic study of 41 cases. Am J Surg Pathol 1990;14:439-48.

14 Kaudewitz P, Stein H, Dallenbach F, et al. Primary and secondary cutaneous $\mathrm{Ki}-1+(\mathrm{CD} 30+)$ anaplastic large cell lymphomas. Morphologic, immunohistologic, and

15 Beljaards RC, Meijer CJLM, Scheffer E, et al. Prognostic significance of $\mathrm{CD} 30$ (Ki-1/Ber-H2) expression in primary cutaneous large cell lymphomas of $\mathrm{T}$-cell origin A clinicopathologic and immunohistochemical study in 20 patients. Am J Pathol 1989;135:1169-78.

16 Sugimoto $\mathrm{H}$, Nakayama F, Yamauchi $\mathrm{T}$, et al. $\mathrm{Ki}-1+$ cutaneous lymphoma. Gene rearrangement analysis of tumour cells in tissue and short-term culture of a patient Arch Dermatol 1988;124:405-8.

17 Sterry W, Korte B, Schubert C. Pleomorphic T-cell lymphoma and large-cell anaplastic lymphoma of the skin: A morphological, immunophenotypical and ultrastructural study of two typical cases. Am J Dermatopathol 1989, 11:112-23.

18 Lindholm JS, Barron DR, Williams ME, Swerdlow SH. $\mathrm{Ki}-1$ positive cutaneous large cell lymphoma of $\mathrm{T}$ ype: Report of an indolent subtype. J Am Acad Dermatol 1989;20:342-8.

19 Schwarting R, Gerdes J, Stein H. Ber-H2: A new monoclonal antibody of the $\mathrm{Ki}-1$ family for the detection Hodgkin's disease in formaldehyde fixed tissue In McMichael AJ, ed. Leucocyte typing III Oxford: Oxford University Press, 1987:574-5. 
20 Hall PA, D'Ardenne AJ, Stansfeld AG. Paraffin section immunohistochemistry. II. Hodgkin's disease and large cell anaplastic (Ki-1) lymphoma. Histopathology 1988; 13:161-9.

21 Macaulay WL. Lymphomatoid papulosis. A continuing selfhealing eruption, clinically benign-histologically malignant. Arch Dermatol 1968;97:23-30.

22 Weinman VF, Ackerman AB. Lymphomatoid papulosis. A critical review and new findings. Am J Dermatopathol critical review

23 Willemze R, Meyer CJLM, Van Vloten WA, Scheffer E. The clinical and histological spectrum of lymphomatoid papulosis. Br J Dermatol 1982;107:131-44.

24 Flynn KJ, Dehner LP, Gajl-Peczalska KJ, Dahl MV Ramsay N, Wang N. Regressing atypical histiocytosis: A cutaneous proliferation of atypical neoplastic histiocytes with unexpectedly indolent biologic behaviour. Cancer 1982;49:959-70.

25 Rilke F, Giardini R, Lombardi L. Recurrent atypical cutaneous histiocytosis. In: Sommers SC, Rosen PP, Fechner RE, eds. Pathology annual part two. New York: Appleton Century Crofts, 1985:29-58.

26 Headington JT, Roth MS, Schnitzer B. Regressing atypical histiocytosis: A review and critical appraisal. Sem Diagnost Pathol 1987:4:28-37.

27 Hsu SM, Jaffe ES. Leu M1 and peanut agglutinin stain the neoplastic cells of Hodgkin's disease. Am J Clin Pathol 1984;82:29-32.

28 Kurtin PJ, Pinkus GS. Leucocyte common antigen-a diagnostic discriminant between haematopoietic and nonhaematopoietic neoplasms in paraffin sections using monoclonal antibodies: correlation with immunologic studies and ultrastructural localisation. Hum Patho 1985;16:353-65.

29 Norton AJ, Ramsay AD, Smith SH, Beverley PCL, Isaacson PG. Monoclonal antibody (UCHL1) that recognises nor$\mathrm{mal}$ and neoplastic T cells in routinely fixed tissues. J Clin Pathol 1986;39:399-405.

30 Stross WP, Warnke RA, Flavell DJ, et al. Molecule detected in formalin fixed tissue by antibodies MT1, DF-T1 and L60 (Leu-22) corresponds to CD43 antigen. J Clin Patho 1989;42:953-61.

31 Mason DY, Krissansen GW, Davey FR, Crumpton MJ, Gatter KC. Antisera against epitopes resistant to denaturation on T3 (CD3) antigen can detect reactive and neoplastic $T$ cells in paraffin embedded tissue biopsy

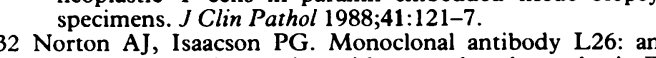
antibody that is reactive with normal and neoplastic $B$ lymphocytes in routinely fixed and paraffin wax embedded tissues. J Clin Pathol 1987;40:1405-12.

33 Hall PA, D'Ardenne AJ, Butler MG, Habeshaw JR, Stansfeld AG. New marker of B lymphocytes, MB2: comparison with other lymphocyte subset markers active in conventionally processed tissue sections. J Clin Pathol 1987;40:151-6.

34 Brandtzaeg P, Jones DB, Flavell DJ, et al. Mac 387 antibody and detection of formalin resistant myelomonocytic $\mathbf{L l}$ and det. J Clin Pathol 1988;41:963-70.

35 Pulford KAF, Rigney EW, Micklem KJ, et al. KP1: A new monoclonal antibody that detects a monocyte/macrophage monoclonal antibody that detects a monocyte/macrophage Clin Pathol 1989;42:414-21.

36 Smoller BR, McNutt NS, Hsu A. HMB-45 recognizes stimulated melanocytes. J Cutan Pathol 1988;16:49-53.

37 Schwarting R, Gerdes J, Dürkop H, Falini B, Pileri S, Stein $\mathrm{H}$. Ber-H2: A new anti-Ki-1 (CD30) monoclonal antibody directed at a formol-resistant epitope. Blood 1989;74: 1678-89.

38 White RM, Patterson JW. Cutaneous involvement in Hodgkin's disease. Cancer 1985;55:1136-45.

39 Hanson CA, Jaszcz W, Kersey JH, et al. True histiocytic lymphoma: histopathologic, immunophenotypic and genotypic analysis. Br J Haematol 1989;73:187-98.

40 Ralfkiaer E, Delsol G, O'Connor NTJ, et al. Malignant lymphomas of true histiocytic origin. A clinical, hislymphomas of true histiocytic origin. A clinical, his-
tological immunophenotypic and genotypic study. $J$ Pathol 1990;160:9-17.

41 Kadin M, Nasu K, Sako D, Said J, Vonderheid E. Lymphomatoid papulosis. A cutaneous proliferation of phomatoid papulosis. A cutaneous proliferation of activated helper T cells expressing Hodgkin's disea

42 Weiss LM, Wood GS, Trela M, Warnke RA, Sklar J. Clonal $T$-cell populations in lymphomatoid papulosis. Evidence of a lympho-proliferative origin for a clinically benign disease. N Engl J Med 1986;315:475-9.

43 Salhany KE, Cousar JB, Greer JP, Casey TT, Fields JP, Collins RD. Transformation of cutaneous $T$ cell lymphoma to large cell lymphoma. A clinicopathologic and immunologic study. Am J Pathol 1988;132:265-77. 